IZA DP No. 733

Wage Elasticity of the Teacher

Supply in Switzerland

Stefan C. Wolter

Stefan Denzler

March 2003 


\title{
Wage Elasticity of the Teacher Supply in Switzerland
}

\author{
Stefan C. Wolter \\ Swiss Coordination Centre for Research in Education, \\ University of Berne and IZA Bonn \\ Stefan Denzler \\ Swiss Coordination Centre for Research in Education
}

Discussion Paper No. 733
March 2003

IZA

P.O. Box 7240

D-53072 Bonn

Germany

Tel.: +49-228-3894-0

Fax: +49-228-3894-210

Email: iza@iza.org

This Discussion Paper is issued within the framework of IZA's research area Internationalization of Labor Markets. Any opinions expressed here are those of the author(s) and not those of the institute. Research disseminated by IZA may include views on policy, but the institute itself takes no institutional policy positions.

The Institute for the Study of Labor (IZA) in Bonn is a local and virtual international research center and a place of communication between science, politics and business. IZA is an independent, nonprofit limited liability company (Gesellschaft mit beschränkter Haftung) supported by the Deutsche Post AG. The center is associated with the University of Bonn and offers a stimulating research environment through its research networks, research support, and visitors and doctoral programs. IZA engages in (i) original and internationally competitive research in all fields of labor economics, (ii) development of policy concepts, and (iii) dissemination of research results and concepts to the interested public. The current research program deals with (1) mobility and flexibility of labor, (2) internationalization of labor markets, (3) welfare state and labor market, (4) labor markets in transition countries, (5) the future of labor, (6) evaluation of labor market policies and projects and (7) general labor economics.

IZA Discussion Papers often represent preliminary work and are circulated to encourage discussion. Citation of such a paper should account for its provisional character. A revised version may be available on the IZA website (www.iza.org) or directly from the author. 
IZA Discussion Paper No. 733

March 2003

\section{ABSTRACT}

\section{Wage Elasticity of the Teacher Supply in Switzerland}

In order to learn more about the wage elasticity of the teacher supply in Switzerland, this paper estimates wages for teachers and non-teachers. The data used are ten surveys of graduates of all Swiss universities for the period of 1981-1999. The data allows us to estimate the wage elasticity for entry wages of upper secondary school teachers. In the cases examined, the wage differential is highly significant and shows a wage elasticity for the teacher supply of $0.12 \%$ to $0.18 \%$. This elasticity is substantially lower than what has been found in the literature for other countries. It is probably due to the fact that teachers' salaries are generally high in Switzerland - teachers here enjoy a positive wage differential over those in other occupations, the opposite of what is normally the situation elsewhere.

JEL Classification: $\quad$ 12, J24, J45

Keywords: $\quad$ wage elasticity, labour supply, teachers, university graduates, Switzerland

Corresponding author:

Stefan C. Wolter

Swiss Co-ordination Centre for Research in Education (SKBF)

Entfelderstrasse 61

$\mathrm{CH}-5000$ Aarau

Switzerland

Tel.: + 41628352390

Fax: + 41628352399

Email: stefanwolter@yahoo.de 


\section{Introduction $^{1}$}

Reports of teacher shortages in most of the OECD countries have accumulated in recent years (see OECD, 2002 or Santiago 2002). This problem raises questions that we all too often are unable to answer without greater knowledge of the labour market for teachers, knowledge that is generally not at hand outside the English-speaking countries.

One easily available avenue for eliminating the shortage of teachers, or for better balancing supply and demand, is via wage formation. Although a number of studies have been conducted on wages and teacher quality, and teachers' unions never tire of emphasizing that better salaries would result in better teachers, less has been said about whether higher wages would also motivate more people to choose teaching as a profession. The relationship between teachers' salaries and their quantitative supply has never been researched in most countries, primarily because the statistics needed to do so are often lacking.

The labour market for teachers in those countries for which we do have such studies (primarily the United States and Great Britain), is not especially comparable with the market in Switzerland, and it is thus questionable how far the results of these studies hold for other countries. The main difference is that in English-speaking countries, teachers normally tend to earn less than people who have a similar education but are employed in other occupations. Since this is not the case in Switzerland, it is interesting to examine whether the purely quantitative high wage elasticity of the teacher supply found by these studies also applies here.

\footnotetext{
${ }^{1}$ The authors would like to thank the Federal Statistical Office of Switzerland for the provision of the data and the support that came with it.
} 
The goal of this study is to empirically test the wage elasticity of the supply of upper secondary school teachers in Switzerland. To do this, we use data collected between 1981 and 1999 on graduates of all of Switzerland's traditional academic university institutions. The paper is divided into six sections. We begin with a theoretical analysis of supply and demand in the labour market for teachers, and derive from this the importance of the wage elasticity of the teacher supply. We then briefly describe the state of research as set forth in the international empirical literature. This is followed by a description of the data, presentation of the model employed, and a discussion of our findings. The last section summarizes the results.

\section{The teacher supply and wages}

An educational system's demand for teachers (D) is determined by two factors primarily (see Figure 1). The first is the assumption that the number of teachers sought will depend in the short term on the number of school classes, so that the number of pupils at a given moment, combined with the standard class size set by the educational authorities, gives us a more or less predetermined level of demand for teachers $\left(\mathrm{Q}^{\mathrm{g}}\right)$. The second factor is the amount of money (E) that the political process provides for the overall educational system in the budget. This budget allocation enables varying numbers of teachers to be hired if their salaries are not fixed in advance. However, the educational system's quantitative demand for teachers (D), in combination with its budget allocation $(\mathrm{E})$, implies a wage $\left(\mathrm{W}^{\mathrm{S}}\right)$.

A normal teacher supply curve (S) does not, of course, automatically mean that the supply and demand curves will intersect at equilibrium wage $\left(\mathrm{W}^{\mathrm{e}}\right)$ that would result solely from the two curves because the government's budget restrictions would not permit this. In the case shown in Figure 1, budget restrictions would produce a wage of $\mathrm{W}^{*}$, which would lie below the 
equilibrium wage $\mathrm{W}^{\mathrm{e}}$. Under the given circumstances, the equilibrium wage would be located at the intersection of $\mathrm{S}$ and $\mathrm{E}$, i.e. at $\mathrm{W}^{*}$. However, substantially fewer teachers $\left(\mathrm{Q}^{*}\right)$ would be employed at this salary than originally planned $\left(\mathrm{Q}^{\mathrm{g}}\right)$. The difference would be a shortage of teachers, $\mathrm{TS}_{\mathrm{g}}$. Such a shortage could, of course, be eliminated by raising the wage, but this is only possible if the educational system's budget is increased from E to E' (see also Figure 2; which would yield equilibrium $\mathrm{EQ}^{1}$ ).

Figure 1: Teacher supply and demand (1)

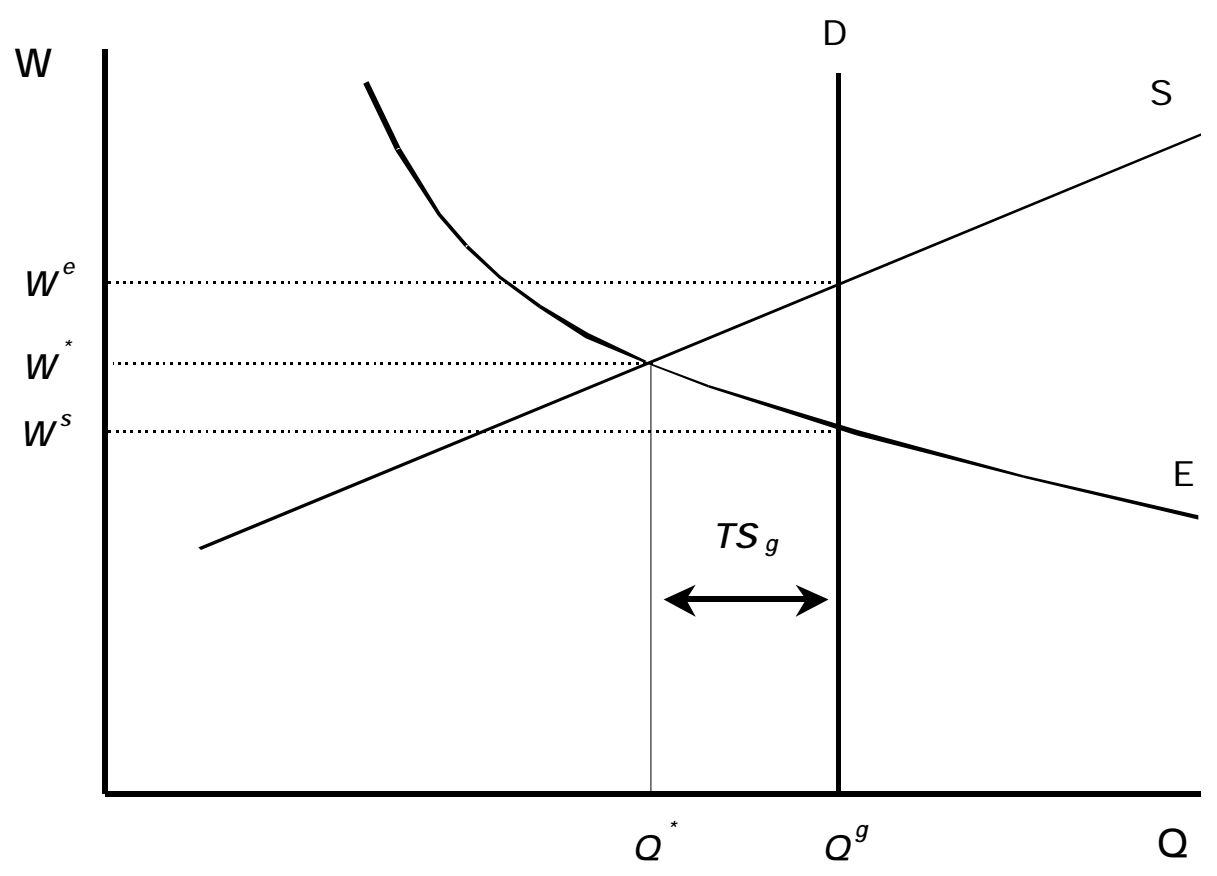

Since this is probably a rare occurrence even in times of teacher shortages, educational policymakers have to resort to other means to alleviate the problem. Another possibility is to look for more teachers while keeping the wage at $\mathrm{W}^{\mathrm{e} 3}$. However, this will only succeed, and then only partially, if there is a supply ( $S^{\prime}$ ) of potential teachers who are prepared to work for a lower wage (equilibrium $\mathrm{EQ}^{2}$ ). These people cannot be the same as those described by the 
usual supply curve $(\mathrm{S})$. It also means that the new teachers normally will not be able to provide the same quality of instruction as the original group of teachers.

Finally, educational policymakers can, of course, use still other means to lower the demand for teachers (new D'), by increasing class size, for example. The smaller demand that results from this organizational measure enables equilibrium $\mathrm{EQ}^{3}$ to be achieved with the same budget $(\mathrm{E})$.

Figure 2: Teacher supply and demand (2)

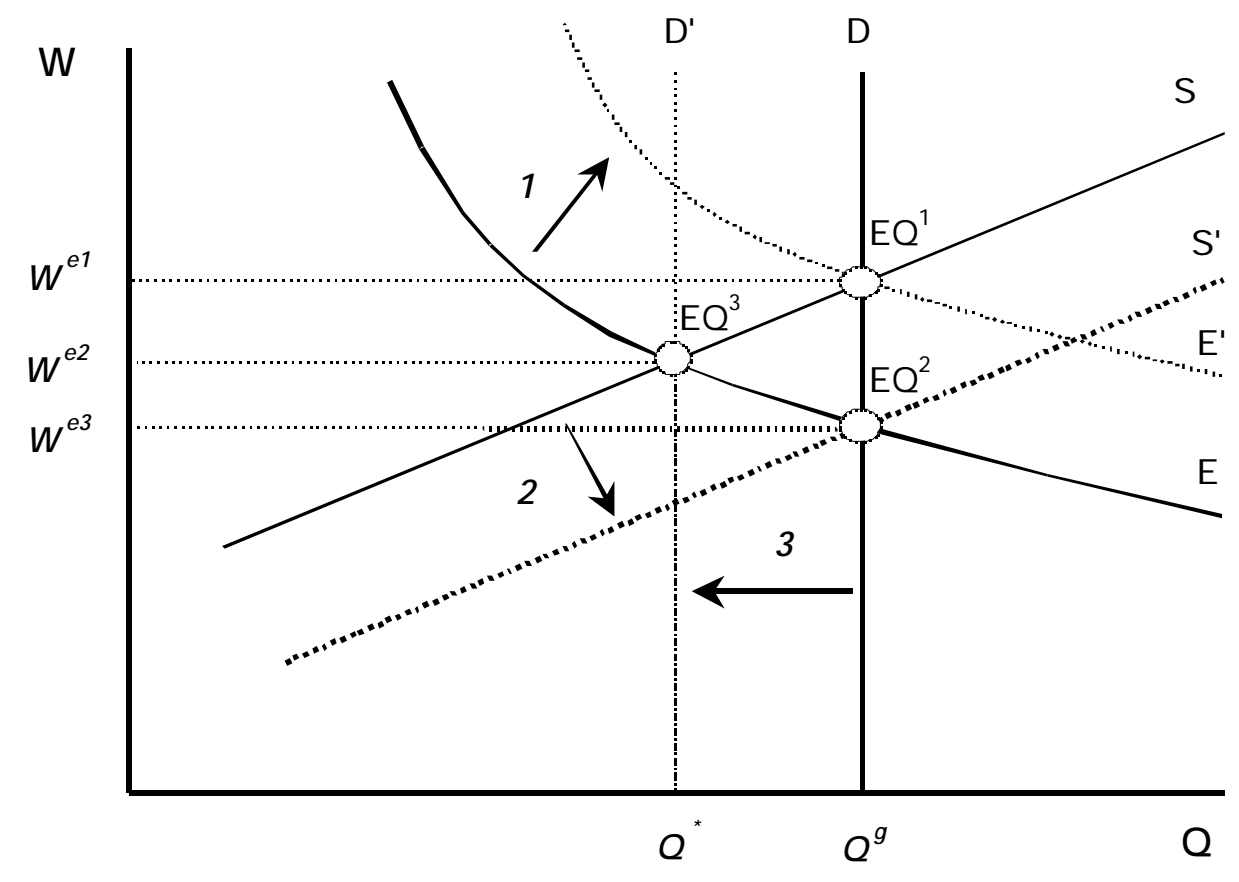

Thus policymakers have various means at their disposal to eliminate an initial disequilibrium (TS $\mathrm{g}_{\mathrm{g}}$ in Figure 1), but they will only be able to do so without damaging the quality of the educational system if they increase the budget and thus teachers' wages. The two other solutions described above will cause the quality of instruction to deteriorate.

If one decides to raise wages in order to eliminate a shortage of teachers, the next question that immediately arises is how elastically will the supply of teachers respond to changes in the 
wage? Without this knowledge, policymakers are unable to judge how much the budget has to be increased in order to eliminate the shortage.

\section{A brief review of the literature}

A number of authors, primarily in English-speaking countries, have demonstrated the existence of wage effects on what people decide to study and their choice of occupation. Thus the relative incomes of teachers strongly influence whether a student decides to go into teaching. Manski (1987) has calculated a wage elasticity for the supply of teachers of between 2 and 3. Dolton (1990) has shown in various analyses using graduate data from England that the relative income of teachers and relative wage growth are both determining factors when choosing a profession. The higher that teachers' wages are relative to other occupations, the more likely it is that graduates will go into teaching (Dolton 1990; Dolton and Makespeace 1993; Chevalier et al. 2002). Hanushek and Pace (1995) find that in addition to the length of the educational training programme, and the certification examination, relative wages ${ }^{2}$ also influence the supply of teachers, but they dispute whether this effect has a strong influence on the choice of studies (which is in this paper equated with occupational choice).

Most authors agree that income influences how long someone will remain a teacher. Almost all studies show that increasing teachers' wages would result in a significantly lower turnover and/or exit rate $^{3}$ (Chevalier et al. 2002; Hanushek et al. 2001, 1999; Dolton and Van der

\footnotetext{
${ }^{2}$ Using probit estimates the authors find that relative income has a weak but still significant effect: a wage increase of $10 \%$ would result in a rise of 0.7 percentage points among graduates of universities (Hanushek and Pace, 1995, p. 112ff.).

${ }^{3}$ Chevalier et al. (2002), for example, have calculated that a $10 \%$ rise in the relative teacher's wage would improve the probability of the average UK university graduate still teaching after six years in the profession by 10 percentage points. This means that a good 24\% (or approximately 11,000 more) of the 1990 graduate cohort would still have been teaching in 1996 instead of the $14 \%$ that in fact remained in the profession. A $10 \%$ relative wage increase would also reduce the likelihood of quitting by $9 \%$ (Dolton and Van der Klaauw 1995, 442).
} 
Klaauw 1995, 1996, 1999; Gritz and Theobald 1996; Mont and Rees 1996, Murnane 1991; Murnane and Olsen 1990).

However, Hanushek et al. (1999, 2001) argue that local school factors and pupils' characteristics (origin, social class, performance, etc.) have a stronger influence on the mobility of teachers than the wage or wage differential. ${ }^{4}$

The literature cited shows that, in general, teachers and students seem to react to income differences as well as to non-monetary incentives in the same manner as people in other occupations, and that they also take financial factors into consideration when deciding whether to become or remain a teacher.

However, this does not mean that higher wages automatically also attract better teachers. The effect of income on teaching quality is a controversial issue in the literature and is difficult to test methodologically. Little empirical evidence has been offered one way or the other up to now; most studies have not been able to demonstrate an effect (Hanushek 1997 and 1999; Manski 1987). In theory, general wage increases expand the supply of teachers in the labour market, but the quality of instruction will only improve if the employment process is selective. ${ }^{5}$ Loeb and Page (2000) argue that because different school districts show different teacher supply curves, the lack of empirical evidence is due to the methods employed being inadequate. They go on to say that we thus have to control for alternative occupational opportunities and for non-pecuniary school-related parameters (profiles of the pupils, their parents, the school, community, etc.) if we want to be able to estimate the relevant wage elasticities. Using an appropriate model (a wage-quality diagram), the authors find that

\footnotetext{
${ }^{4}$ Hanushek et al. 2001, 12: "Teachers systematically favor higher achieving, non-minority, non-low income students."
} 
teachers' incomes have a significant effect on their pupils' school performance (as measured by the high school dropout rate and the proportion who go on to college). ${ }^{6}$ Because teachers' qualifications correlate strongly with school characteristics and the demographic makeup of a student body, ${ }^{7}$ Loeb proposes specific incentives (such as targeted wage increases and/or improving the facilities of less attractive schools) to offset such discrepancies (Loeb 2000, $15)$.

Temin (2002) relates the sharp drop in teachers' relative wages that took place in the United States in the 1970s and 1990s to both changes in the labour market for women and cutbacks in the public funds available to local communities. Women's wages have gone up as their employment opportunities have broadened, so that non-teaching occupations are now much more attractive to them. ${ }^{8}$ This means, however, that relative teacher wages have declined especially for female teachers, a factor that partially explains the shrinkage in the supply of women in teaching. Temin defines the demand for teachers as a function of both price (wage) and quality, ${ }^{9}$ arguing that a market in which quality depends on wages (among other factors) will not exhibit a single equilibrium but rather multiple equilibria of differing degrees of stability (see also Figure 2 of this paper). ${ }^{10}$ The problem is how to move from a stable low-wage, low-quality equilibrium to one of high wages and high quality.

\footnotetext{
${ }^{5}$ Regarding the problem of teacher selection, see primarily Ballou and Podgursky 1995, 1998; and Miles and Darling-Hammond 1997.

${ }^{6}$ A $10 \%$ wage increase (which would offset the relative decline in wages that occurred in the 1980s) would reduce the high school dropout rate by more than 3\%, and lift the number of those enrolling in college by $8 \%$ (Loeb and Page 2000, 406).

${ }^{7}$ Teachers in urban schools are substantially less qualified than those in suburban and rural areas; the same is also true for schools with a high proportion of poor, black, or Hispanic pupils (Loeb 2000, 12ff.).

${ }^{8}$ The wage premium of women with some graduate education compared to female teachers was less than $20 \%$ at the end of the 1970s, versus more than $40 \%$ today. Women with only a college education but no graduate education (i.e. comparable to primary school teachers) earn about $10 \%$ more (Temin 2002, 13ff.).

${ }^{9}$ Analogously to Akerlof's "lemon" model.

${ }^{10}$ Direct wage effect: declining demand. Indirect effect: rising demand. If the indirect effect is stronger than the direct, we have a rising demand curve with multiple equilibria (Temin 2002, 5).
} 


\section{The data}

Since there is little statistical material available on teachers and their wages in Switzerland, and what exists is often inadequate, it was not that easy to find a data set suitable for answering our questions. The data material employed here is thus limited in various respects. Because, however, it is longitudinal in nature, it enables us to separate some of the economic influences from those that are structural in nature.

The first limitation concerns the type of teacher for whom data is available. Since educational policies in Switzerland are the responsibility of the cantons, the training that teachers receive is not uniform, a fact that tends to negatively influence the statistics that are collected. The situation is a bit better for upper secondary teachers, not least because teachers at this level are normally required to have a traditional university education.

Switzerland has conducted a full census of graduates of traditional universities every two years for more than 20 years now, and of graduates of the universities of applied science, for about 10 years. Our study focuses on the data collected for the former group, whom we will refer to as "university graduates", and for whom we use the complete series of surveys conducted from 1981 to 1999 (to our knowledge, this is the first time this has been done). The 2001 survey had been completed by the time of our study, but the data not yet released. Since the data set available to us contains ten waves of cross-sectional data for university graduates, we are thus able to combine the advantages of cross-sectional and longitudinal observation by means of a pooled cross-section analysis. In particular, the ability to observe the same question over a period of 20 years allows us to supplement the data set with other longitudinal data like economic indicators. We can also test the influence of systemic changes such as the impact of educational reforms and similar measures. 
The data describing systemic changes were gathered by surveying all of the traditional universities. They were first sent a written questionnaire; we then followed this up in many instances with oral interviews. The questions asked concerned any reforms of their study programmes, changes in admission requirements, or other similarly far-reaching modifications of their institution's organization that had taken place during the previous 20 years. For changes which we thought might have an effect on the question of interest to us - the occupations chosen by their graduates - we constructed dummy variables for the institution starting from when the change was expected to have influenced the graduates.

One disadvantage associated with this data set was that we have had to limit our analysis to the first job held after graduation, i.e. we are only able to determine whether wage elasticity is significant for the graduate initial decision concerning whether to go into teaching. We are unable to examine whether wage elasticity plays a role in deciding at a later date whether to remain a teacher or change one's occupation. For this we would need regular follow-up surveys. Such surveys were not carried out for the period covered here, but they are planned for the future.

\section{Empirical model}

The empirical procedure employed is a relatively simple and classical one, well adapted to the data. In the end, the proposition of interest to us and which we want to test is whether the wage differential between teaching and other occupations influences the likelihood of becoming a teacher. To do this, we estimate a probit model that includes, in addition to personality characteristics (vector $X$ ), an individually estimated wage differential for each 
person observed $\left(\ln W^{T}-\ln W^{O}\right)$ as an independent (i.e. explanatory) variable for the probability of the person choosing teaching as a profession after graduation $(T)$.

$T_{t}=\beta_{0}+\beta_{1}\left(\ln W_{t}^{T}-\ln W_{t}^{o}\right)+\beta_{2} X_{t}+u_{1}$

The individual wage differential can be estimated in various ways. We chose the following method, which is in line with those employed by Dolton (1990) and by Chevalier et al. (2002). ${ }^{11}$ It can be broken down into three stages.

We first estimate a structural equation which we then use to calculate the selection correction in the subsequent wage equations. The purpose of the equation is to capture the composition of the teaching population and of non-teaching university graduates so that we can account for wage effects related to differences in the makeup of the two groups. Since one does not become a teacher by sheer accident, we cannot assume that the wages of non-teachers are a good predictor for teachers' wages if the latter do not choose to go into teaching, and vice versa.

We estimate a reduced form probit model and calculate from this (equation 2) the inverse Mills ratio $(\lambda)$, which we insert into the wage estimates (equations $3 \& 4$ ) to correct for selection bias.

$$
T_{t}=\beta_{0}+\beta_{1} X_{t}+u_{1}
$$

$$
\ln W_{t}^{T}=\delta_{0}^{o}+\delta_{1}^{o} X_{t}^{\prime}+\delta_{2}^{o} \lambda+u_{2}
$$

\footnotetext{
${ }^{11}$ Chevalier et al. (2002) also employ matching, which we do not use.
} 
$\ln W_{t}^{o}=\delta_{0}^{o}+\delta_{1}^{o} X_{t}^{\prime}+\delta_{2}^{o} \lambda+u_{3}$

One of the most important points concerning this selection correction is that the vector $(\mathrm{X})$ in equation 2 must not be identical with the vector ( $\left.\mathrm{X}^{\prime}\right)$ in equations 3 and 4 (identification problem). In other words, we need to have factors that only influence the likelihood of becoming a teacher and which we can assume do not directly affect teachers' wages. Whether this identification process succeeds is entirely dependent on how well we choose which personality characteristics and other variables are to be included or excluded.

In our empirical analysis we now take account of two variables in vector $X^{\prime}$ of equation 2 that do not form part of vector $X^{\prime}$ in the subsequent equations: the university at which the diploma was earned, and the type of certificate required for admission to the university. This may be surprising at first, but all of the Swiss universities proved to be so similar in quality in the past that we can assume that while the nature of the diploma earned was relevant for wages, the university attended was not. On the other side we can assume that due to specialisation of some of the universities, the choice of the university has an impact on the likelihood to become a teacher.

Most other studies have included parents' education as a variable influencing a graduate's choice of occupation, but not directly influencing wage. Since our data set did not contain any information on parents' education, we replaced this with the certificate required for admission. In the past Switzerland has exhibited a high degree of social reproduction, especially with regard to access to universities. We can thus assume that those who use a gymnasium diploma to enter university - our reference group - normally have parents with university level degrees, and that the minority of students who enter university with some other certificate most probably have parents who do not have university level degrees. We can 
also assume that the certificate providing admission to a university has some influence on which occupation is chosen after graduation, but no direct influence on wage.

We also have variables which we expect to directly affect the wage but which should not have any direct influence on occupational choice. These are the two economic variables GDP and unemployment, and the workplace's location (because there is a certain gap between the wages paid in large cities and in other areas). We also take into account whether the person holds a full-time or part-time job. It is interesting to note that university graduates normally receive a better entry wage for a part-time position than for one that is full-time, a situation exactly the opposite of what applies for the average of all wages. Although certain occupations unquestionably have more part-time positions than others, we do not assume that this directly influences the choice of occupation.

Thus we can use equations 3 and 4 to calculate the entry wages for teachers $\left(\ln W^{\mathrm{T}}\right)$ and non-teachers $\left(\ln W^{O}\right)$. For each graduate included in our data set we estimate a teaching and a non-teaching wage as well as the difference between the two, which we then insert into equation 1 . The influence of this variable describes the wage elasticity of the teacher supply, at least as regards the first job after graduation.

\section{The results}

The estimates for equations 2 to 4 were performed for the group of teachers as a whole and broken down into gymnasium and non-gymnasium teachers (see Tables 1 and 2). While they show that the qualitative statements are correct for the aggregate group and for the two subgroups, the quantitative results vary. This is to be expected: although the graduates have a 
wide variety of teaching occupations at different school levels to choose from (generally primary through upper secondary), gymnasium teachers on average have the best wage prospects.

The labour markets for the two categories of teachers have also moved in different directions (see Figures 1 and 2 in the Appendix). In the case of gymnasium teachers, the proportion of graduates who chose this for their first job dropped sharply in the mid-1980s and then held steady at about $6 \%$ thereafter; but while their wage differential over non-teachers also declined at first, it then rose sharply again, especially in the first half of the 1990s. The proportion of graduates who chose to go into other areas of teaching did not go up or down dramatically but fluctuated continuously around approximately 5\%. Their wage differential, however, which is lower on average than for gymnasium teachers, plunged in the 1980s and then recovered somewhat in the following decade. If we were to base our interpretation on Figures 1 and 2 solely, we would not necessarily conclude that the proportion of graduates who choose to become teachers would react sensitively to the anticipated wage differential.

We can interpret the regressions in Tables 2 and 3 as showing that the profile of graduates who tend to become teachers differs from that of other graduates on the basis of age and field of study, and that men predominate significantly among gymnasium teachers. This contrasts sharply with the predominance of women at the primary and lower secondary levels. It is also interesting that the certificate providing access to the university sometimes plays a significant role, i.e. students who come to the university already equipped with a primary or secondary school teaching certificate are more likely to go back to teaching after graduation. The easing of university admission requirements that took place in the early 1980s (more students with a teacher diploma before entering the university) stimulated a stronger inflow of people that 
were more likely to take up teaching after university. But this inflow (see also Figure 4) lessened again in the following decade.

Most of the system variables we constructed are not significant, and for this reason, the results are not shown separately, with one exception: When the University of Berne changed its admission requirements to allow primary school teachers to study in any field they wanted to, the number of graduates who later decided to become gymnasium teachers went up significantly (but not, however, the proportion who chose other areas of teaching). This created somewhat of a dilemma for the Canton of Berne. The good thing was that primary school teachers admitted to the university were more likely to return to teaching after graduation, but the bad thing was that they were also more motivated to leave their profession as primary teachers to attend university. Although this filled in holes at the upper secondary level and even prevented their arising, it created some problems for the canton's primary schools.

Lambdas were constructed from the initial reduced probit estimate and then employed as variables in the relevant wage regressions to correct for selection bias. However, the lambda is significant in only one of the four wage regressions. The wage regressions do not present any major surprises when compared to the wage estimates for Switzerland contained in the literature even though we estimate entry wages solely. One element of interest, and which agrees with earlier results, is that men earn more than women even when we control for all observable differences (however, we did not test this effect for possible time dependence). Comparing the wages of teachers and non-teachers, it also striking that nationality seems to play a significant role only for the teachers, and that their wages do not exhibit any dependence on economic conditions. Unemployment has a significant negative influence on non-teachers' wages, but not on those of teachers. It is precisely this difference in the 
dependence of wage formation on economic conditions that explains the sharp increase in the wage differential between gymnasium teachers and non-teachers that took place in the first half of the 1990s (Figure 1 in the Appendix). The differential is explained by the stagnation in teachers' wages, and a sharp drop in entry wages for non-teachers.

If we now use the two wage regressions to calculate for each graduate a separate wage for teaching and non-teaching, we have the mean results shown in Table 1.

Table 1: $\quad$ Predicted log gross annual earnings for teachers and non-teachers in their first job following graduation (CHF in 1999 values in brackets)

\begin{tabular}{|c|c|c|c|}
\hline & Teachers & Non-teachers & Difference \\
\hline Teaching job & $\begin{array}{c}3.877 \\
\text { (CHF 77’246) }\end{array}$ & $\begin{array}{c}3.769 \\
\text { (CHF 69’337) }\end{array}$ & 0.108 \\
\hline Non-teaching job & $\begin{array}{c}3.755 \\
\text { (CHF 68’374) } \\
\end{array}$ & $\begin{array}{c}3.700 \\
\text { (CHF 64'715) }\end{array}$ & 0.055 \\
\hline Difference & $\begin{array}{c}0.122 \\
\left(C H F 8^{\prime} 872\right)\end{array}$ & $\begin{array}{c}0.069 \\
\left(\mathrm{CHF} 4{ }^{\prime} 622\right)\end{array}$ & \\
\hline
\end{tabular}

We see that teachers in general have a higher entry wage than non-teachers. It is also the case that non-teachers can expect to receive a higher wage if they choose teaching as their initial occupation, but the anticipated difference in wages between the two options is substantially higher $(0.122$ versus 0.069$)$ for graduates who do in fact become teachers. This indicates that the initial employment choice is a rational decision. This result most certainly is not to be interpreted as meaning that all graduates should have become teachers because of the generally higher entry wage; after all, we know only this initial wage and can only deduce how their income will perform thereafter, something that can vary greatly between teachers and non-teachers. ${ }^{12}$

\footnotetext{
12 Although we have no information in this data set on wages throughout the life cycle of a person, we know from other sources that the entry wages are representative insofar that the discounted life income stream that
} 
Our regression results are shown in Tables 4 and 5 (in the Appendix). The expected individual wage differential has a significant positive influence on the likelihood of choosing teaching as one's initial occupation for both subgroups, with the marginal effect larger for non-gymnasium teachers than for gymnasium teachers. The latter already have a higher wage differential. If the wage differential in favour of teachers is increased by $10 \%$, the proportion of a graduate cohort that chooses to go into teaching is 1.2 percentage points higher for gymnasium teachers, ${ }^{13}$ and 1.8 percent higher for other teachers. Although the field of study remains one of the main factors determining whether teaching will be chosen as an occupation even after the wage differential is accounted for, the teacher supply in the past has reacted very sensitively to the relative wage at the time of entry into a profession. Comparison of the two categories of teachers, and comparison with the wage elasticities found in other countries, leads us to think that elasticity is high primarily where the differential is either very small or even in favour of non-teachers.

After determining that a significant wage elasticity of supply exists for both gynmasium and other teachers, the question arises - especially as regards gymnasium teachers (see also Figure 1) - why the proportion of graduates did not increase strongly in the 1990s when the wage differential in favour of teachers rose so sharply? In accordance with the results shown in Tables 2 and 4, this is primarily because men have accounted for a steadily and notably smaller proportion of graduates over the last 20 years (see Figure 4), and men become gymnasium teachers significantly more often than women. Two other factors are that the proportion of people who study literature, mathematics and the sciences, fields that supply particularly large numbers of teachers, has been consistently small; and the proportion of difference for men, the difference is substantial for women. 
graduates who already have a teaching certificate before entering the university has been decreasing since the mid-1980s. Interpreted this way, we can assume that the proportion of graduates choosing to become gymnasium teachers in the 1990s would have declined even further if the positive wage differential had not offset this trend. This naturally raises the question of how the labour market for upper secondary school teachers will develop should the overall labour market enjoy another prolonged recovery and thus reduce the wage differential between teachers and non-teachers.

\section{Conclusions}

The labour market for teachers is special in at least two respects. Firstly, in most of the OECD countries the dominance of public schools means that the state is virtually the sole employer and thus a monopsonist. Secondly, the market is characterized by frequent disequilibria that take the form of a shortage or excess of teachers. One possible reason for this might be that the state in its role of employer provokes these disequilibria through the rigidities of its wage-setting process and education budgets. However, we also know that governmental actors lack the knowledge needed for active wage formation. The wage elasticity of the teacher supply is a critical point in this respect because it must be ascertained before we can estimate the effects that changes in the employment rate for teachers will have on the education budget.

In order to learn more about the wage elasticity of the teacher supply in Switzerland, this paper has estimated wages for teachers and non-teachers, with these estimates including a selectivity correction for wage distortions that might possibly be caused by the occupational

\footnotetext{
${ }^{13}$ For 1999, this would mean some 100 more graduates would choose to become gymnasium teachers if their
} 
selection process. However, the data allows us to estimate wage elasticity only for entry wages and for upper secondary school teachers. These estimates provide us with two expected entry wages for each university graduate, one for the case that the graduate decides to become a teacher, and one for the case that she/he does not. These individual wage estimates enable us to calculate individual wage differentials which we then use as the explanatory variable for estimating the likelihood of a graduate going into teaching. In the cases examined, the wage differential is significant and shows a wage elasticity for the teacher supply of $0.12 \%$ to $0.18 \%$. This elasticity is substantially lower than what we have found in the literature for other countries. It is probably due to the fact that teachers' salaries are generally high in Switzerland - teachers here enjoy a positive wage differential over those in other occupations, the opposite of what is normally the situation elsewhere.

Our results also show that the expected wage differential between teaching and other occupations is larger for teachers than for non-teachers. This result leads us to suppose that university graduates choose their initial occupation on a rational basis, and that they take monetary factors into consideration when making this decision.

Finally, our analyses show that the number of graduates who choose to become teachers (and especially gymnasium teachers) would of necessity have gone down in the 1990s in light of the changes in the demographic composition of the student population that have taken place over the last 20 years. That this did not occur was a consequence of the recession resulting in a significant increase in the wage differential in favour of teachers. 


\section{Literature}

Ballou, D., Podgursky, M. (1995). Recruiting smarter teachers, Journal of Human Resources, 30 (2), $326-338$.

Ballou, D., Podgursky, M. (1998). Teacher Recruitment and Retention in Public Schools, Journal of Policy Analysis and Management, 17 (3), 393-417.

Chevalier, A., Dolton, P., McIntosh, St. (2002). Recruiting and Retaining Teachers in the UK: An Analysis of Graduate Occupation Choice from the 1960s to the 1990s, London: Centre for Economics of Education.

Dolton, P. (1990). The economics of UK teacher supply: the graduate's decision, Economic Journal, 100, Conference papers, 91-104.

Dolton, P., Klaauw, W. van der (1995). Leaving teaching in the UK: a duration analysis, Economic Journal, 105, 431-444.

Dolton, P., Klaauw, W. van der (1996). Teaching Salaries and Teacher Retention, in Becker, W. E., Baumol, W. J., Assessing Educational Practices: the Contribution of Economics, Cambridge MA: MIT Press, 239-272.

Dolton, P., Makespeace, G. H. (1993). Female labour force participation and the choice of occupation. The supply of teachers, European Economic Review, 37, 1393-1411, North Holland.

Dolton, P., Klaauw, W. van der (1999). The turnover of teachers: a competing risks explanation, Review of Economics and Statistics, 81, 543-552.

Gritz, R.M., Theobald, N.D. (1996). The Effects of School District Spending Priorities on Length of Stay in Teaching, Journal of Human Resources, 31 (3), 477-512.

Hanushek, E.A. (1997). Assessing the effects of school resources on student performance: An update, Educational Evaluation and Policy Analysis 19, 2, 141-164.

Hanushek, E.A., Pace, R.R. (1995). Who Chooses To Teach (and Why)?, Economics of Education Review, 14 (2), 101-117.

Hanushek, Kain, J., Rivkin, E.G. (1999). Do Higher Salaries Buy Better Teachers? NBER Working Paper Series, No. 7082, National Bureau of Economic Research, Cambridge MA.

Hanushek, Kain, J., Rivkin, E.G. (2001). Why Public Schools Loose Teachers? NBER Working Paper Series, No. 8599, National Bureau of Economic Research, Cambridge MA.

Loeb, S. (2000). How Teachers' Choices affect what a Dollar can buy: Wages and Quality in K-12 Schooling. Paper prepared for the Education Finance Research Consortium.

Loeb, S., Page, M.E. (2000). Examining the link between teacher wages and student outcomes: The importance of alternative Labor Market Opportunities and non-pecuniary variation, The Review of Economic and Statistics, 82, 3, 393-408.

Manski, C.F. (1987). Academic ability, earnings, and the decision to become a teacher: evidence from the National Longitudinal Study of the High School Class of 1972, in Wise, D. (ed) Public Sector Payrolls, Chicago IL: University of Chicago Press.

Miles, K.H., Darling-Hammond, L. (1997). Rethinking the allocation of teaching resources: some lessons from high performing schools, Paper prepared for the University of Wisconsin-Madison, Center for Education Research, Consortium for Policy Research in Education.

Mont, D., Rees, D.I. (1996). The Influence of Classroom Characteristics on High School Teacher Turnover, Economic Inquiry, 34 (Jan), 152-167.

Murnane, R.M. (1991). Who will teach? Policies that matter, Cambridge, Mass.: Harvard University Press.

Murnane, R.M., Olsen, R.J. (1990). The effects of salaries and opportunity costs on length of stay in teaching: evidence from North Carolina, Journal of Human Resources, 25, 106-124.

OECD (2002): The Teaching Workforce: Concerns and Policy Challenges, Education Policy Analysis 2002, Paris: OECD, 65-87.

Santiago, P. (2002): Teacher Demand and Supply: Improving Teaching Quality and addressing Teacher Shortages - A Literature Review and a Conceptual Framework for Future Work, Education Working Papers No. 1, Paris: OECD.

Temin, P. (2002). Teacher Quality and the Future of America. NBER-Working Paper No. 8898, Cambridge MA. 


\section{Appendices}

Figure 1: Percentage of graduates who become gymnasium teachers, and the wage differential between teachers and non-teachers

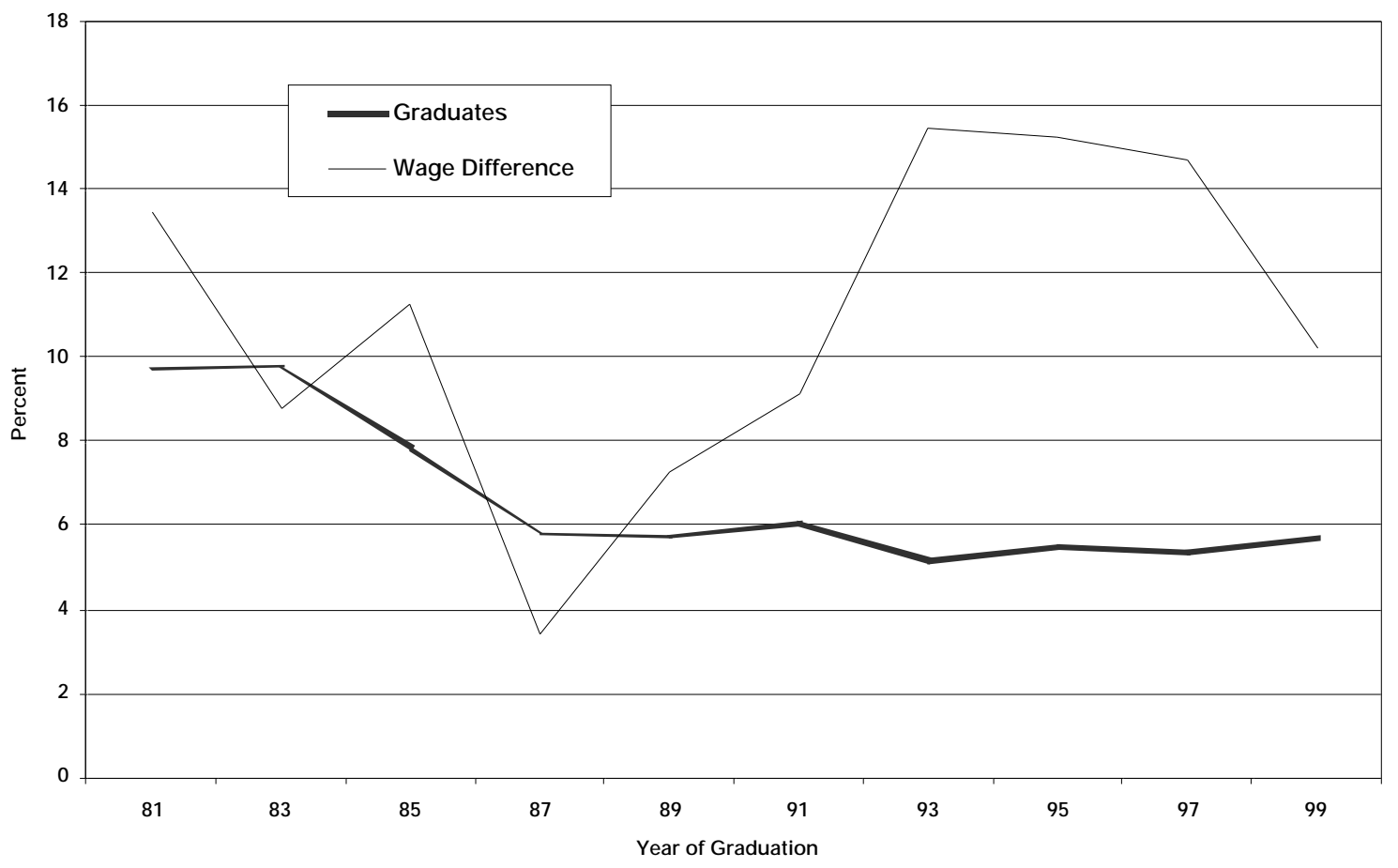

Figure 2: $\quad$ Percentage of graduates who become non-gymnasium teachers, and the wage differential between teachers and non-teachers

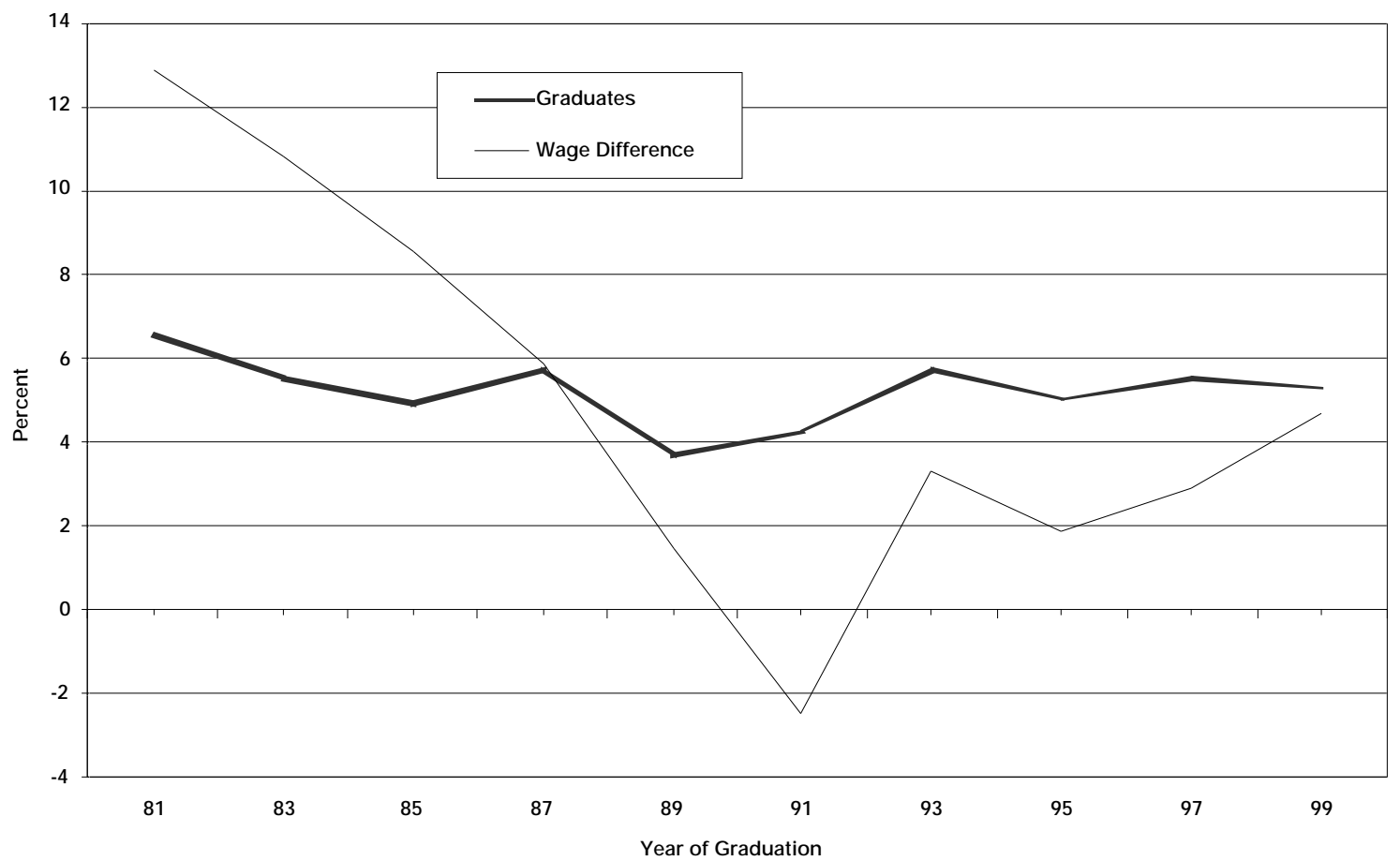


Figure 3: $\quad$ Percentage of graduates in fields that do and do not supply large numbers of teachers

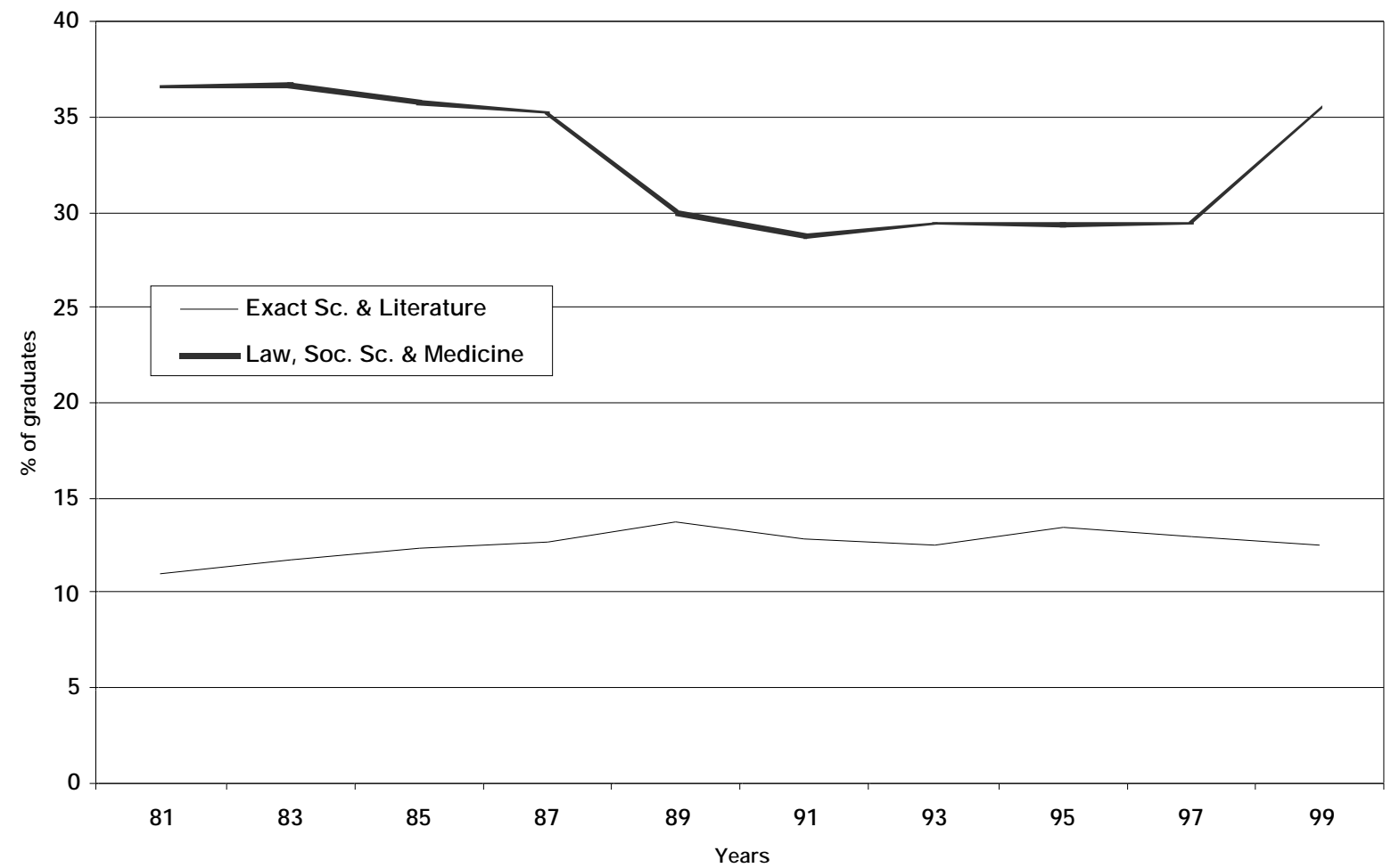

Figure 4: $\quad$ Percentage of male graduates, and graduates who enter university with a primary or lower secondary school teaching certificate

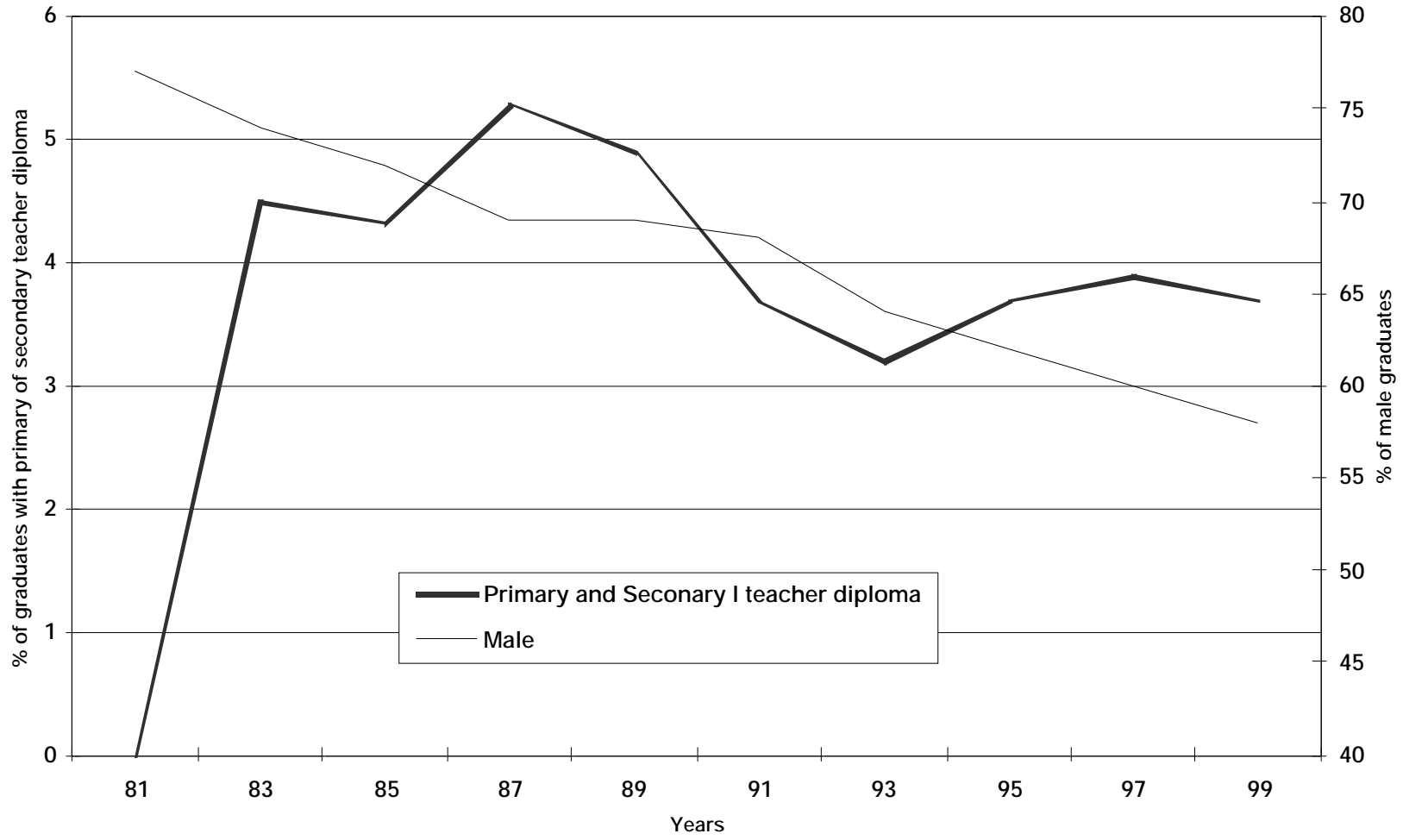


Table 2: Determinants of entry wages for gymnasium teachers

\begin{tabular}{|c|c|c|c|}
\hline Variables & Selection & Teachers & Non-teachers \\
\hline Male & $0.122 *$ & $0.049 *$ & $0.060^{*}$ \\
\hline Age & $0.017 *$ & $0.020 *$ & $0.025 *$ \\
\hline University of Berne & $-0.679 *$ & & \\
\hline University of Basel & $-0.171 *$ & & \\
\hline University of Lucerne & -0.004 & & \\
\hline University of Fribourg & $-0.190 *$ & & \\
\hline University of Geneva & $-0.230 *$ & & \\
\hline University of Lausanne & $0.151 * *$ & & \\
\hline Federal Institute of Technology in Lausanne & $-0.894 *$ & & \\
\hline University of Neuchâtel & $-0.343 *$ & & \\
\hline University of St. Gallen & $-0.388 *$ & & \\
\hline Federal Institute of Technology in Zurich & $-0.309 *$ & & \\
\hline Graduate year 1981 & $0.359 *$ & -0.035 & $-0.086^{*}$ \\
\hline Graduate year 1983 & $0.353^{*}$ & $-0.064 * *$ & $-0.041 *$ \\
\hline Graduate year 1985 & $0.145 * *$ & -0.025 & $-0.045^{*}$ \\
\hline Graduate year 1987 & -0.038 & $-0.084 *$ & $-0.020 * *$ \\
\hline Graduate year 1991 & 0.032 & Dropped & Dropped \\
\hline Graduate year 1993 & -0.039 & 0.033 & $0.027 *$ \\
\hline Graduate year 1995 & 0.014 & -0.003 & $-0.029 *$ \\
\hline Graduate year 1997 & -0.038 & Dropped & Dropped \\
\hline Graduate year 1999 & -0.059 & -0.052 & $-0.023 *$ \\
\hline French-speaking part of Switzerland & $0.132 * *$ & $-0.232 *$ & $-0.115^{*}$ \\
\hline Italian-speaking part of Switzerland & -0.030 & $-0.115^{* *}$ & $-0.173^{*}$ \\
\hline Nationality Swiss & $0.238^{*}$ & $0.072 * *$ & -0.000 \\
\hline Gross domestic product & & -0.006 & -0.001 \\
\hline Unemployment rate & & -0.010 & $-0.021 *$ \\
\hline Part-time worker & & $0.124 *$ & $0.089 *$ \\
\hline Zurich & & $-0.058 *$ & $0.068 *$ \\
\hline Basel & & $-0.128 *$ & $-0.061 *$ \\
\hline Berne & & -0.038 & $0.080 *$ \\
\hline Zug & & 0.112 & $0.071 *$ \\
\hline Geneva & & $0.112 *$ & -0.014 \\
\hline Natural sciences & $0.844 *$ & -0.010 & $-0.041 *$ \\
\hline Natural sciences $+\mathrm{TD}^{14}$ & $2.500 *$ & -0.007 & -0.099 \\
\hline Theology & $1.564 *$ & $-0.403^{*}$ & $-0.134 *$ \\
\hline Theology + TD & $2.494 *$ & -0.220 & 0.016 \\
\hline Literature and languages & $1.564 *$ & -0.062 & $-0.100 *$ \\
\hline Literature and languages + TD & $2.494 *$ & -0.030 & -0.003 \\
\hline History & $0.934 *$ & -0.076 & $-0.136^{*}$ \\
\hline History + TD & $2.404^{*}$ & -0.041 & -0.023 \\
\hline Social sciences & -0.092 & -0.020 & $-0.132 *$ \\
\hline Social sciences + TD & $1.376^{*}$ & 0.209 & -0.027 \\
\hline Economics & -0.065 & 0.050 & $0.123^{*}$ \\
\hline Economics + TD & $1.604 *$ & 0.079 & $0.162 *$ \\
\hline Law & $-0.929 *$ & 0.005 & $-0.367 *$ \\
\hline Exact sciences & $1.167 *$ & -0.023 & $0.124 *$ \\
\hline Exact sciences + TD & $2.871^{*}$ & 0.021 & 0.028 \\
\hline Engineering & $-0.558 *$ & -0.136 & $0.082 *$ \\
\hline Vocational certificate & $-0.160 *$ & & \\
\hline Certificate as primary teacher & 0.109 & & \\
\hline Certificate as lower secondary teacher & $0.414 *$ & & \\
\hline University of applied sciences diploma & -0.242 & & \\
\hline Admission criteria change, University of Berne & $0.346^{* *}$ & & \\
\hline Lambda & & 0.652 & -0.014 \\
\hline Constant & $-2.884 *$ & 3.283 & 3.088 \\
\hline F test & & 14.79 & 250.97 \\
\hline Log-likelihood & -4874.8 & & \\
\hline Pseudo (or adjusted) $\mathrm{R}^{2}$ & 0.3734 & 0.250 & 0.252 \\
\hline Observations & 32931 & 1678 & 27634 \\
\hline
\end{tabular}

*,** indicate significance at the $1 \%$ and 5\% levels respectively. The reference graduate is female, had an A-level university entrance certificate, graduated in 1989 in medicine from the University of Zurich, and works full-time in the German-speaking part of Switzerland.

${ }^{14} \mathrm{TD}=$ Teacher diploma 
Table 3: Determinants of entry wages for non-gymnasium teachers

\begin{tabular}{|c|c|c|c|}
\hline Variables & Selection & Teachers & Non-teachers \\
\hline Male & -0.042 & $0.081 *$ & $0.061^{*}$ \\
\hline Age & $0.013^{*}$ & $0.017 *$ & $0.025^{*}$ \\
\hline University of Berne & -0.127 & & \\
\hline University of Basel & $-0.039 *$ & & \\
\hline University of Lucerne & $0.807 *$ & & \\
\hline University of Fribourg & $0.151 * *$ & & \\
\hline University of Geneva & $0.214^{*}$ & & \\
\hline University of Lausanne & 0.018 & & \\
\hline Federal Institute of Technology in Lausanne & $-0.762 *$ & & \\
\hline University of Neuchâtel & $0.250 * *$ & & \\
\hline University of St. Gallen & -0.052 & & \\
\hline Federal Institute of Technology in Zurich & $0.377 *$ & & \\
\hline Graduate year 1981 & $0.449 *$ & 0.044 & $-0.088 *$ \\
\hline Graduate year 1983 & $0.232 *$ & -0.042 & $-0.041 *$ \\
\hline Graduate year 1985 & $0.133 * *$ & 0.000 & $-0.045^{*}$ \\
\hline Graduate year 1987 & $0.266^{*}$ & 0.016 & $-0.026 * *$ \\
\hline Graduate year 1991 & 0.058 & Dropped & Dropped \\
\hline Graduate year 1993 & $0.250^{*}$ & 0.034 & $0.027 * *$ \\
\hline Graduate year 1995 & 0.112 & -0.010 & $-0.027 * *$ \\
\hline Graduate year 1997 & $0.173 * *$ & Dropped & Dropped \\
\hline Graduate year 1999 & $0.123 * *$ & -0.010 & $-0.025 * *$ \\
\hline French-speaking part of Switzerland & $0.325 *$ & $-0.139 *$ & $-0.121 *$ \\
\hline Italian-speaking part of Switzerland & $0.351 *$ & $-0.152 * *$ & $-0.178^{*}$ \\
\hline Nationality Swiss & $0.173 * *$ & $0.140 *$ & -0.005 \\
\hline Gross domestic product & & 0.011 & -0.002 \\
\hline Unemployment rate & & -0.008 & $-0.021 *$ \\
\hline Part-time worker & & $0.114 *$ & $0.095^{*}$ \\
\hline Zurich & & -0.027 & $0.063 *$ \\
\hline Basel & & $-0.096 * *$ & $-0.064 *$ \\
\hline Berne & & -0.027 & $0.073^{*}$ \\
\hline Zug & & 0.103 & $0.070^{*}$ \\
\hline Geneva & & $0.086 * *$ & $-0.023 * *$ \\
\hline Natural sciences & $0.313 *$ & -0.103 & $-0.030 * *$ \\
\hline Natural sciences + TD & $1.054 *$ & -0.107 & 0.033 \\
\hline Theology & -0.242 & $-0.083 *$ & $-0.141 *$ \\
\hline Literature and languages & $1.069 *$ & $-0.126^{*}$ & $-0.068 *$ \\
\hline Literature and languages $+\mathrm{TD}$ & $1.290^{*}$ & -0.054 & -0.044 \\
\hline History & $0.767 *$ & $-0.147 *$ & $-0.125 *$ \\
\hline History + TD & $1.152 *$ & -0.014 & -0.009 \\
\hline Social sciences & 0.557 & $-0.083 * *$ & $-0.142 *$ \\
\hline Social sciences + TD & $1.274 *$ & -0.007 & -0.019 \\
\hline Economics & -0.069 & 0.017 & $0.124^{*}$ \\
\hline Economics + TD & $1.890^{*}$ & 0.080 & $0.132 * *$ \\
\hline Law & $-0.275^{*}$ & $-0.180 * *$ & $-0.367 *$ \\
\hline Exact sciences & $0.265^{*}$ & -0.050 & $0.121 *$ \\
\hline Exact sciences + TD & $0.461 * *$ & -0.073 & $0.102 * *$ \\
\hline Engineering & $-1.222 *$ & 0.181 & $0.082 *$ \\
\hline Vocational certificate & -0.004 & & \\
\hline Certificate as primary teacher & $0.750^{*}$ & & \\
\hline Certificate as lower secondary teacher & $0.700^{*}$ & & \\
\hline University of applied sciences diploma & 0.137 & & \\
\hline Admission criteria change, University of Berne & 0.160 & & \\
\hline Lambda & & $0.304 * *$ & -0.020 \\
\hline Constant & $-2.951 *$ & $3.154^{*}$ & $3.091^{*}$ \\
\hline F test & & 8.44 & 272.86 \\
\hline Log-likelihood & -5296.68 & & \\
\hline Pseudo (or adjusted) $\mathrm{R}^{2}$ & 0.205 & 0.166 & 0.259 \\
\hline Observations & 32929 & 1346 & 27964 \\
\hline
\end{tabular}

**** indicate significance at the $1 \%$ and $5 \%$ levels respectively. The reference graduate is female, had an A-level university entrance certificate, graduated in 1989 in medicine from the University of Zurich, and works full-time in the German-speaking part of Switzerland. 
Table 4: Determinants of becoming a gymnasium teacher

\begin{tabular}{|c|c|c|}
\hline Variables & Probit & Marginal effect \\
\hline Male & $0.158^{*}$ & 0.005 \\
\hline Age & $0.036^{*}$ & 0.001 \\
\hline University of Berne & $-0.650 *$ & -0.014 \\
\hline University of Basel & $-0.220 *$ & -0.006 \\
\hline University of Lucerne & -0.105 & -0.003 \\
\hline University of Fribourg & $-0.200 * *$ & -0.006 \\
\hline University of Geneva & $-0.553 *$ & -0.013 \\
\hline University of Lausanne & $0.170 * *$ & 0.007 \\
\hline Federal Institute of Technology in Lausanne & $-0.959 *$ & -0.014 \\
\hline University of Neuchâtel & $-0.306 * *$ & -0.008 \\
\hline University of St. Gallen & $-0.445^{*}$ & -0.010 \\
\hline Federal Institute of Technology in Zurich & $-0.329 *$ & -0.009 \\
\hline Graduate year 1981 & -0.030 & -0.001 \\
\hline Graduate year 1983 & $0.303 *$ & 0.014 \\
\hline Graduate year 1985 & 0.008 & 0.000 \\
\hline Graduate year 1987 & 0.083 & 0.003 \\
\hline Graduate year 1991 & -0.097 & -0.003 \\
\hline Graduate year 1993 & $-0.340 *$ & -0.009 \\
\hline Graduate year 1995 & $-0.321 *$ & -0.009 \\
\hline Graduate year 1997 & $-0.319 *$ & -0.009 \\
\hline Graduate year 1999 & $-0.130 * *$ & -0.004 \\
\hline French-speaking part of Switzerland & $0.215^{*}$ & 0.008 \\
\hline Italian-speaking part of Switzerland & $-0.443 *$ & -0.010 \\
\hline Nationality Swiss & 0.011 & 0.000 \\
\hline Natural sciences & $0.726^{*}$ & 0.053 \\
\hline Natural sciences + TD & $1.930^{*}$ & 0.376 \\
\hline Theology & $0.719^{*}$ & 0.053 \\
\hline Theology + TD & $3.371 *$ & 0.864 \\
\hline Literature and languages & $1.376^{*}$ & 0.169 \\
\hline Literature and languages + TD & $2.438 *$ & 0.564 \\
\hline History & $0.702 *$ & 0.050 \\
\hline History + TD & $2.230 *$ & 0.521 \\
\hline Social sciences & -0.417 & -0.010 \\
\hline Social sciences + TD & $0.429 *$ & 0.024 \\
\hline Economics & $0.204 * *$ & 0.008 \\
\hline Economics + TD & $1.800^{*}$ & 0.326 \\
\hline Law & $-2.289 *$ & -0.034 \\
\hline Exact sciences & $1.622 *$ & 0.246 \\
\hline Exact sciences + TD & $2.696^{*}$ & 0.672 \\
\hline Engineering & 0.103 & 0.004 \\
\hline Vocational certificate & $-0.139 * *$ & -0.004 \\
\hline Certificate as primary teacher & 0.057 & 0.002 \\
\hline Certificate as lower secondary teacher & $0.344 *$ & 0.018 \\
\hline University of applied sciences diploma & -0.202 & -0.006 \\
\hline Admission criteria change, University of Berne & $0.382 * *$ & 0.019 \\
\hline Expected wage differential $\left(\ln W^{T}-\ln W^{O}\right)$ & $3.345 *$ & 0.117 \\
\hline Constant & $-3.369 *$ & \\
\hline Observed probability & 0.059 & \\
\hline Log-likelihood & -4294.10 & \\
\hline Pseudo (or adjusted) $\mathrm{R}^{2}$ & 0.389 & \\
\hline Observations & 31144 & \\
\hline
\end{tabular}


Table 5: Determinants of becoming a non-gymnasium teacher

\begin{tabular}{|c|c|c|}
\hline Variables & Probit & Marginal effect \\
\hline Male & $-0.098 * *$ & -0.005 \\
\hline Age & $0.043^{*}$ & 0.002 \\
\hline University of Berne & -0.166 & -0.007 \\
\hline University of Basel & -0.072 & -0.003 \\
\hline University of Lucerne & $0.649 * *$ & 0.060 \\
\hline University of Fribourg & 0.088 & 0.005 \\
\hline University of Geneva & -0.117 & -0.005 \\
\hline University of Lausanne & 0.021 & 0.001 \\
\hline Federal Institute of Technology in Lausanne & $-0.879 *$ & -0.020 \\
\hline University of Neuchâtel & $0.197 * *$ & 0.012 \\
\hline University of St. Gallen & $0.314^{*}$ & -0.007 \\
\hline Federal Institute of Technology in Zurich & $-0.191 * *$ & 0.019 \\
\hline Graduate year 1981 & $-0.191 * *$ & -0.008 \\
\hline Graduate year 1983 & $0.277^{*}$ & 0.017 \\
\hline Graduate year 1985 & -0.117 & -0.005 \\
\hline Graduate year 1987 & 0.032 & 0.002 \\
\hline Graduate year 1991 & $0.172 * *$ & 0.010 \\
\hline Graduate year 1993 & 0.095 & 0.005 \\
\hline Graduate year 1995 & -0.022 & -0.002 \\
\hline Graduate year 1997 & 0.058 & 0.010 \\
\hline Graduate year 1999 & -0.014 & -0.001 \\
\hline French-speaking part of Switzerland & $0.122 * *$ & 0.007 \\
\hline Italian-speaking part of Switzerland & 0.065 & 0.003 \\
\hline Nationality Swiss & $-0.366^{*}$ & -0.025 \\
\hline Natural sciences & $0.475^{*}$ & 0.036 \\
\hline Natural sciences + TD & $1.400^{*}$ & 0.237 \\
\hline Theology & $-0.450 *$ & -0.014 \\
\hline Literature and languages & $1.087^{*}$ & 0.135 \\
\hline Literature and languages $+\mathrm{TD}$ & $1.432 *$ & 0.252 \\
\hline History & $0.716^{*}$ & 0.067 \\
\hline History + TD & $0.982 *$ & 0.122 \\
\hline Social sciences & $0.283^{*}$ & 0.018 \\
\hline Social sciences + TD & $0.959 *$ & 0.118 \\
\hline Economics & $0.318^{*}$ & 0.020 \\
\hline Economics + TD & $1.665^{*}$ & 0.328 \\
\hline Law & $-1.046^{*}$ & -0.029 \\
\hline Exact sciences & $0.827^{*}$ & 0.086 \\
\hline Exact sciences + TD & $0.981 *$ & 0.122 \\
\hline Engineering & $-1.511 *$ & -0.026 \\
\hline Vocational certificate & 0.001 & 0.000 \\
\hline Certificate as primary teacher & $0.559 *$ & 0.047 \\
\hline Certificate as lower teacher & $0.470 *$ & 0.037 \\
\hline University of applied sciences diploma & 0.102 & 0.037 \\
\hline Admission criteria change, University of Berne & 0.131 & 0.007 \\
\hline Expected wage differential $\left(\ln W^{T}-\ln W^{O}\right)$ & $3.656^{*}$ & 0.179 \\
\hline Constant & $-3.129 *$ & \\
\hline Observed probability & 0.047 & \\
\hline Log-likelihood & -4574.90 & \\
\hline Pseudo (or adjusted) $\mathrm{R}^{2}$ & 0.226 & \\
\hline Observations & 31142 & \\
\hline
\end{tabular}




\section{IZA Discussion Papers}

\begin{tabular}{|c|c|c|c|c|}
\hline No. & Author(s) & Title & Area & Date \\
\hline 717 & $\begin{array}{l}\text { A. Hijzen } \\
\text { H. Görg } \\
\text { R. C. Hine }\end{array}$ & $\begin{array}{l}\text { International Fragmentation and Relative Wages } \\
\text { in the UK }\end{array}$ & 2 & $02 / 03$ \\
\hline 718 & E. Schlicht & Consistency in Organization & 1 & $02 / 03$ \\
\hline 719 & $\begin{array}{l}\text { J. Albrecht } \\
\text { P. Gautier } \\
\text { S. Vroman }\end{array}$ & $\begin{array}{l}\text { Equilibrium Directed Search with Multiple } \\
\text { Applications }\end{array}$ & 3 & $02 / 03$ \\
\hline 720 & T. Palokangas & $\begin{array}{l}\text { Labour Market Regulation, Productivity- } \\
\text { Improving R\&D and Endogenous Growth }\end{array}$ & 3 & $02 / 03$ \\
\hline 721 & $\begin{array}{l}\text { H. Battu } \\
\text { M. Mwale } \\
\text { Y. Zenou }\end{array}$ & $\begin{array}{l}\text { Do Oppositional Identities Reduce Employment } \\
\text { for Ethnic Minorities? }\end{array}$ & 1 & $02 / 03$ \\
\hline 722 & $\begin{array}{l}\text { C. K. Spiess } \\
\text { F. Büchel } \\
\text { G. G. Wagner }\end{array}$ & $\begin{array}{l}\text { Children's School Placement in Germany: Does } \\
\text { Kindergarten Attendance Matter? }\end{array}$ & 6 & $02 / 03$ \\
\hline 723 & $\begin{array}{l}\text { M. Coles } \\
\text { B. Petrongolo }\end{array}$ & $\begin{array}{l}\text { A Test between Unemployment Theories Using } \\
\text { Matching Data }\end{array}$ & 3 & $02 / 03$ \\
\hline 724 & $\begin{array}{l}\text { J. T. Addison } \\
\text { R. Bailey } \\
\text { W. S. Siebert }\end{array}$ & $\begin{array}{l}\text { The Impact of Deunionisation on Earnings } \\
\text { Dispersion Revisited }\end{array}$ & 2 & $02 / 03$ \\
\hline 725 & S. Habermalz & An Examination of Sheepskin Effects Over Time & 1 & $02 / 03$ \\
\hline 726 & S. Habermalz & $\begin{array}{l}\text { Job Matching and the Returns to Educational } \\
\text { Signals }\end{array}$ & 1 & $02 / 03$ \\
\hline 727 & $\begin{array}{l}\text { M. Raiser } \\
\text { M. Schaffer } \\
\text { J. Schuchardt }\end{array}$ & Benchmarking Structural Change in Transition & 4 & $02 / 03$ \\
\hline 728 & $\begin{array}{l}\text { M. Lechner } \\
\text { J. A. Smith }\end{array}$ & What is the Value Added by Caseworkers? & 6 & $02 / 03$ \\
\hline 729 & $\begin{array}{l}\text { A. Voicu } \\
\text { H. Buddelmeyer }\end{array}$ & $\begin{array}{l}\text { Children and Women's Participation Dynamics: } \\
\text { Transitory and Long-Term Effects }\end{array}$ & 3 & $02 / 03$ \\
\hline 730 & $\begin{array}{l}\text { M. Piva } \\
\text { M. Vivarelli }\end{array}$ & $\begin{array}{l}\text { Innovation and Employment: Evidence from } \\
\text { Italian Microdata }\end{array}$ & 2 & $02 / 03$ \\
\hline 731 & $\begin{array}{l}\text { B. R. Chiswick } \\
\text { N. DebBurman }\end{array}$ & $\begin{array}{l}\text { Educational Attainment: Analysis by Immigrant } \\
\text { Generation }\end{array}$ & 1 & $02 / 03$ \\
\hline 732 & $\begin{array}{l}\text { A. Falk } \\
\text { A. Ichino }\end{array}$ & Clean Evidence on Peer Pressure & 5 & $03 / 03$ \\
\hline 733 & $\begin{array}{l}\text { S. Wolter } \\
\text { S. Denzler }\end{array}$ & $\begin{array}{l}\text { Wage Elasticity of the Teacher Supply in } \\
\text { Switzerland }\end{array}$ & 2 & $03 / 03$ \\
\hline
\end{tabular}

An updated list of IZA Discussion Papers is available on the center's homepage www.iza.org. 